\title{
Partisipasi Orang Tua Terhadap Pembelajaran Online di Rumah Ditinjau Dari Fase Kelas di Sekolah Dasar
}

\author{
Nur Khasanah ', Mujiyem Sapti ${ }^{1}$ (D), Rintis Rizkia Pangestika ${ }^{1}$ \\ ' Pendidikan Guru Sekolah Dasar, Fakultas Keguruan dan Ilmu Pendidikan, Universitas Muhammadiyah \\ Purworejo, Indonesia \\ Jl. K.H.A. Dahlan No. 3 \& 6 Purworejo, Jawa Tengah \\ *Corresponding author: khazanahnur412@gmail.com
}

\begin{abstract}
Abstrak: Penelitian ini bertujuan untuk (1) mengetahui bagaimana partisipasi orang tua dalam mendukung kegiatan pembelajaran online pada siswa dan (2) mengetahui apakah terdapat perbedaan partisipasi yang orang tua berikan pada siswa kelas tinggi dan kelas rendah. Penelitian ini merupakan penelitian kuantitatif dengan metode survei. Jumlah subjek dalam penelitian ini yaitu 60 orang tua siswa dari kelas I-VI SD Negeri 1 Seren. Teknik pengambilan sampel dalam penelitian ini adalah probability sampling dengan tipe simple random sampling. Teknik pengumpulan data yang digunakan adalah angket dan dokumentasi. Instrumen yang digunakan adalah lembar angket. Teknik analisis data yang digunakan adalah statistik deskriptif dengan menggunakan rumus persentase dan uji T. Hasil penelitian ini menunjukkan bahwa partisipasi orang tua dalam mendukung kegiatan pembelajaran online pada siswa diberikan dalam bentuk orang tua sebagai: pendidik, pembimbing, motivator, dan fasilitator. Selanjutnya hasil uji hipotesis diperoleh nilai Sig. (2-tailed) 0,000 $<0,05$ menunjukkan terdapat perbedaan partisipasi orang tua terhadap pembelajaran online di rumah ditinjau dari fase kelas di Sekolah Dasar. Rata-rata persentase partisipasi orang tua terhadap pembelajaran online di kelas rendah yaitu $75,14 \%$ lebih besar dibandingkan rata-rata partisipasi orang tua terhadap pembelajaran online di kelas tinggi yaitu $61,85 \%$ sehingga partisipasi orang tua terhadap pembelajaran online di kelas rendah lebih baik.
\end{abstract}

Kata Kunci: Partisipasi Orang Tua, Pembelajaran Online, Fase Kelas Di Sekolah Dasar

\begin{abstract}
This study aims to (1) find out how parents' participation in supporting online learning activities for students and (2) find out whether there are differences in the participation that parents give high class and low class students. This research is a quantitative research with a survey method. The numbers of subjects in this study were 60 parents of students from class I-VI SD Negeri 1 Seren. The sampling technique in this study is probability sampling with the type of simple random sampling. The data collection techniques used were questionnaires and documentation. The instrument used was a questionnaire sheet. The data analysis technique used is descriptive statistics using the percentage formula and the $T$ test. The results of this study indicate that the participation of parents in supporting online learning activities for students is given in the form of parents as: educators, mentors, motivators, and facilitators. Furthermore, the results of the hypothesis test obtained the Sig. (2-tailed) value of $0.000<0.05$, indicating that there are differences in parental participation in online learning at home in terms of the class phase in elementary schools. The average percentage of parental participation in online learning in low classes is $75.14 \%$ greater than the average participation of parents in online learning in high classes, namely $61.85 \%$ so that parents' participation in online learning in low classes is better.
\end{abstract}

Keywords: Parental Participation, Online Learning, Class Phase in Elementary Schools

\section{PENDAHULUAN}

Pendidikan menjadi gerbang utama menuju perubahan bangsa dan negara ke arah yang lebih baik. Pendidikan dapat diperoleh dari lingkungan keluarga, sekolah, dan masyarakat. 
Namun, bidang pendidikan, perekonomian, kesehatan, dan sosial di Indonesia tidak berjalan sebagaimana mestinya dikarenakan pada Maret 2020 negara Indonesia dilanda bencana Covid-19. Badan Nasional Penanggulangan Bencana (BNBP) mengeluarkan surat edaran Nomor 9.A Tahun 2020 yang berisi tentang keputusan penetapan status keadaan darurat bencana wabah penyakit akibat Covid-19 di Indonesia. BNBP menghimbau agar masyarakat selalu menjaga kesehatan dengan memakai masker, sering mencuci tangan dan menjaga jarak. Nadiem Makarim selaku Menteri Pendidikan dan Kebudayaan Republik Indonesia menghimbau agar pendidikan atau proses belajar mengajar dapat dilaksanakan di rumah dengan tujuan mengurangi kegiatan berkerumun dan memutus mata rantai penyebaran Covid-19. Nadiem Makarim meminta pihak sekolah agar menjalankan kegiatan pembelajaran jarak jauh atau yang biasa disebut dengan pembelajaran online.

Yuliani et al. (2020) menjelaskan bahwa pembelajaran online yaitu kegiatan belajar mengajar yang tidak terikat ruang, waktu, serta kehadiran guru, dengan menggunakan sarana elektronik dan telekomunikasi. Karena pembelajaran online tidak terikat ruang serta kehadiran guru maka untuk mendukung proses kegiatan pembelajaran online di rumah, peran serta atau partisipasi dari orang tua sangat diperlukan. Hal ini sesuai dengan hasil penelitian dari Cahyati \& Kusumah (2020) yaitu kegiatan pembelajaran online dapat meningkatkan kelekatan hubungan orang tua dengan anaknya dan orang tua dapat melihat langsung perkembangan anaknya dalam belajar terutama untuk anak Sekolah Dasar, dimana pada anak Sekolah Dasar ini mereka terbagi menjadi dua fase yaitu fase kelas rendah (kelas 1, 2, \& 3) dan fase kelas tinggi (kelas 4, 5, \& 6).

Partisipasi orang tua menjadi kunci utama dalam keberhasilan pelaksanaan kegiatan pembelajaran online selama siswa di rumah. Dwiningrum (2011) berpendapat bahwa partisipasi merupakan keterlibatan mental dan emosi dari seseorang di dalam situasi tertentu yang mendorong orang lain mencapai pada tujuannya serta ikut bertanggungjawab. Partisipasi orang tua yang dapat diberikan untuk mendukung siswa dalam proses belajar, menurut Somawati, et al. (2020) antara lain dalam bentuk: pengasuh/pendidik, pembimbing, motivator, dan juga sebagai fasilitator. Keempat bentuk partisipasi orang tua tersebut dapat menunjang keberhasilan pelaksanaan pembelajaran online di rumah serta hal baik lainnya yaitu siswa akan merasa semangat dalam belajar.

Pembelajaran online dalam Bahasa Indonesia diterjemahkan sebagai pembelajaran dalam jaringan (pembelajaran daring). Belawati (2019) berpendapat bahwa pembelajaran online adalah suatu pembelajaran yang memanfaatkan teknologi berbasis internet yang berpotensi untuk meningkatkan kualitas dan memeratakan akses masyarakat terhadap pendidikan di Indonesia. Pembelajaran online ini tidak sekedar membagikan materi secara online namun ada juga proses belajar mengajar secara online. Media elektronik seperti televisi, smartphone, maupun laptop memiliki peranan penting sebagai alat penunjang kebutuhan siswa dalam mengikuti pembelajaran online dengan menggunakan aplikasi pendukung seperti: WA (whatsApp), sismart, google classroom, zoom, dan lain sebagainya.

Sekolah Dasar merupakan masa dimana anak-anak banyak mengalami perubahan baik dari segi mental maupun fisik. Dimasa ini anak-anak mulai aktif bermain, bergerak, berkelompok serta menjelajahi dunianya. Berikut ini beberapa sifat khas anak-anak pada masa kelas rendah Sekolah Dasar yang dijelaskan oleh Restian (2019) antara lain: waktu untuk merespon perintah lebih lambat, koordinasi otak tidak sempurna, senang berkelahi, aktif bergerak, bermain, dan mengeksplor seperti memanjat, antusias terhadap bunyi-bunyian yang teratur. Sedangkan karakteristik untuk anak kelas tinggi antara lain: waktu untuk merespon perintah lebih cepat, koordinasi dan harmonisasi otot sempurna, senang bergerak dan bermain. Berdasarkan uraian di atas tentang pentingnya partisipasi orang tua dalam pelaksanaan pembelajaran online, maka peneliti merasa tertarik untuk mengambil judul penelitian "Partisipasi Orang Tua Terhadap Pembelajaran Online Di Rumah Ditinjau Dari Fase Kelas Di Sekolah Dasar". 


\section{METODE PENELITIAN}

Penelitian ini menggunakan jenis penelitian kuantitatif dengan metode komparatif. Pada penelitian ini, peneliti akan melakukan penelitian tentang partisipasi orang tua terhadap pembelajaran online di rumah ditinjau dari fase kelas di Sekolah Dasar. Peneliti akan membandingkan partisipasi orang tua di kelas rendah dan di kelas tinggi. Lokasi yang digunakan peneliti untuk mengambil data yaitu di SD Negeri 1 Seren yang terletak di jalan Kemiri KM.5, Desa Seren, Kecamatan Gebang, Kabupaten Purworejo. Penelitian ini dilaksanakan dalam waktu enam bulan, terhitung dari bulan Juni 2020 sampai bulan November 2020. Populasi dalam penelitian ini adalah seluruh orang tua siswa SD Negeri 1 Seren yang berjumlah 273 orang tua siswa. Sedangkan sampel yang digunakan dalam penelitian ini adalah perwakilan orang tua siswa dari kelas I sampai kelas VI dengan rincian tiap tingkatan kelas peneliti menggambil 10 sampel. Maka jumlah keseluruhan sampel dari kelas I sampai dengan kelas VI adalah 60 orang tua siswa.

Teknik pengambilan sampel dalam penelitian ini adalah probability sampling dengan tipe simple random sampling. Untuk penyusunan instrumen atau alat pengumpul data, variabel-variabel yang digunakan sebagai acuan dalam menyusun angket adalah variabel bebas (pembelajaran online) dan variabel terikat (partisipasi orang tua). Teknik pengumpulan data dalam penelitian ini dilakukan dengan cara menyebarkan angket yang ditujukan kepada orang tua siswa. Orang tua siswa diminta untuk mengisi lembar angket yang berisi 18 butir soal berbentuk pernyataan dengan cara memberikan tanda centang $(\checkmark)$ pada kolom jawaban yang tersedia dengan menjawab soal sesuai dengan keadaan sebenarnya. Agar instrumen penelitian dapat dikatakan sebagai instrumen yang valid dan baik, maka diperlukan uji validitas dan reabilitas instrumen.

Validitas instrumen angket yang digunakan peneliti adalah validitas isi. Uji validitas isi dalam penelitian ini dilakukan oleh dosen PCSD yang dapat memberikan pertimbangan dan memberi keputusan apakah instrumen yang dibuat dapat digunakan oleh peneliti atau tidak. Uji validitas isi angket partisipasi orang tua divalidasi oleh Bapak Suyoto, M.Pd. dan hasil validasi instrumen ini menyatakan bahwa instrumen sudah bisa untuk mengukur variabel partisipasi orang tua. Sedangkan untuk uji reliabilitas dalam penelitian ini menggunakan rumus alpha cronbach menurut Widoyoko (2018) yaitu:

$$
r_{11}=\left[\frac{k}{k-1}\right]\left[1-\frac{\sum \sigma_{b}^{2}}{\sigma_{t}^{2}}\right] \quad \text { (Widoyoko, 2018) }
$$

Menentukan nilai varians dengan rumus sebagai berikut:

$$
\sigma^{2}=\frac{\sum X^{2}-\frac{\left(\sum X\right)^{2}}{N}}{N} \quad \text { (Widoyoko, 2018) }
$$

Keterangan:

$r_{11}=$ reliabilitas instrumen

$\mathrm{k}$ = banyaknya butir pertanyaan atau banyaknya soal

$\sum \sigma_{b}^{2}=$ jumlah varians butir soal

$\sigma_{t}^{2}=$ varians total

$X \quad=$ skor total

Harga kritik untuk uji reliabilitas instrumen ini adalah 0,7, Berdasarkan hasil perhitungan, reliabilitas instrumen angket partisipasi orang tua yaitu 0,710. Artinya, angket partisipasi orang tua memiliki reliabilitas yang baik. Untuk mengetahui bagaimana partisipasi orang tua terhadap pembelajaran online, peneliti menggunakan statistik deskriptif dengan menggunakan rumus persentase. Sedangkan untuk mencari perbedaan partisipasi orang tua di kelas rendah dan kelas tinggi peneliti menggunakan uji beda dua rerata (Uji T). 


\section{Statistik Deskriptif Dengan Menggunakan Persentase}

Analisis statistik deskriptif digunakan untuk mendeskripsikan bagaimana partisipasi orang tua terhadap pembelajaran online. Persentase skor partisipasi orang tua dihitung menggunakan rumus berikut:

$$
\text { Presentase }=\frac{\text { jumlah bagian yang dicari }}{\text { jumlah keseluruhan }} \times 100 \% \quad \text { (Bungin, 2013) }
$$

Apabila skor setiap soal telah dijumlahkan dan dihitung dengan menggunakan rumus persentase, langkah selanjutnya yaitu mengklasifikasikan jumlah skor berdasarkan persentase yang diperoleh hasil seperti pada Tabel 1 berikut.

Tabel 1. Kategori Dari Persentase

\begin{tabular}{cc} 
Persentase & Kategori \\
\hline $81 \%-100 \%$ & Sangat Baik \\
$61 \%-80 \%$ & Baik \\
$41 \%-60 \%$ & Cukup \\
$21 \%-40 \%$ & Kurang \\
$0 \%-20 \%$ & Sangat Kurang \\
\hline Sumber: Widoyoko (2018) &
\end{tabular}

\section{Uji Prasyarat Analisis}

a. Uji Normalitas

Teknik yang digunakan untuk menguji normalitas data yaitu Kolmogorov-Smirnov menurut Zarkasyi (2017). Peneliti menggunakan bantuan SPSS (Statistical Packaged For Sosial Science) versi 25 dalam menghitung uji normalitas data dengan taraf signifikan 0,05. Dengan Kriteria pengujian sebagai berikut:

- $\mathrm{H}_{\mathrm{o}}$ : angka signifikan $>0,05$, maka data berdistribusi normal.

- $\mathrm{H}_{1}$ : angka signifikan $<0,05$, maka data tidak berdistribusi normal.

Untuk kelas rendah diperoleh hasil seperti pada Tabel 2 berikut.

Tabel 2. Hasil Uji Normalitas Data Di Kelas Rendah

\begin{tabular}{lllllll}
\hline Tests of Normality & & & & \\
& \multicolumn{1}{l}{ Kolmogorov-Smirnov } & Shapiro-Wilk & \\
\cline { 2 - 7 } & Statistic & $d f$ & Sig. & Statistic & $d f$ & Sig. \\
\hline Rendah & .124 & 30 & $.200^{*}$ & .928 & 30 & .043 \\
\hline$*$ This is a lower bound of the true significance. & & \\
\hline a. Lilliefors Significance Correction & &
\end{tabular}

Nilai signifikansi $=0,200>0,05$ yang artinya Data Berdistribusi Normal. Untuk kelas tinggi diperoleh hasil seperti pada Tabel 3 berikut.

Tabel 3. Hasil Uji Normalitas Data Di Kelas Tinggi

\begin{tabular}{|c|c|c|c|c|c|c|}
\hline \multicolumn{7}{|c|}{ Tests of Normality } \\
\hline & \multicolumn{3}{|c|}{ Kolmogorov-Smirnova } & \multicolumn{3}{|c|}{ Shapiro-Wilk } \\
\hline & Statistic & $d f$ & Sig. & Statistic & $d f$ & Sig. \\
\hline Tinggi & .133 & 30 & .186 & .953 & 30 & .206 \\
\hline \multicolumn{7}{|c|}{ a. Lilliefors Significance Correction } \\
\hline
\end{tabular}

Nilai signifikansi $=0,186>0,05$ yang artinya Data Berditribusi Normal. 
b. Uji Homogenitas

Untuk menghitung uji homogenitas peneliti menggunakan bantuan SPSS (Statistical Packaged For Sosial Science) versi 25 dalam menghitungnya dengan menggunakan taraf signifikan 0,05. Dengan kriteria pengujian sebagai berikut:

- $\mathrm{H}_{\mathrm{o}}$ : angka signifikan $>0,05$, maka kedua kelompok tersebut variannya homogen.

- $\mathrm{H}_{1}$ : angka signifikan <0,05, maka kedua kelompok tersebut variannya tidak homogen.

Untuk uji homogenitas diperoleh hasil seperti pada Tabel 4 berikut.

Tabel 4. Hasil Uji Homogenitas

\begin{tabular}{|c|c|c|c|c|c|}
\hline \multicolumn{6}{|c|}{ Test of Homogeneity of Variances } \\
\hline & & $\begin{array}{l}\text { Levene } \\
\text { Statistic }\end{array}$ & df1 & df2 & Sig. \\
\hline Skor & Based on Mean & 3.582 & 1 & 58 & .063 \\
\hline Partisipasi & Based on Median & 2.751 & 1 & 58 & .103 \\
\hline & Based on Median and with adjusted df & 2.751 & 1 & 51.411 & .103 \\
\hline & Based on trimmed mean & 3.352 & 1 & 58 & .072 \\
\hline
\end{tabular}

Nilai signifikansi dari hasil uji homogenitas yaitu $0,063>0,05$ yang artinya Data Homogen.

c. Uji Hipotesis (Uji Beda Dua Rerata)

Uji ini digunakan untuk mengetahui ada atau tidaknya perbedaan rerata antara dua variabel yaitu varibel independen dan variabel dependen. Berikut ini rumus yang digunakan untuk menghitung uji beda dua rerata.

$$
\begin{array}{ll}
\mathrm{t}=\frac{\left(\mathrm{X}_{1-X_{2}}\right)}{s p \sqrt{\frac{1}{n_{1}}+\frac{1}{n_{2}}}} & \text { (Sugiyono, 2016) } \\
s p^{2}=\frac{\left(n_{1}-1\right) s_{1}^{2}+\left(n_{2}-1\right) s_{2}^{2}}{n_{1}+n_{2}-2} & \text { (Sugiyono, 2016) }
\end{array}
$$

Dimana $t$ adalah harga statistik yang diuji; $x_{1}$ adalah nilai rata-rata kelas hasil kelas rendah; $x_{2}$ adalah nilai rata-rata kelas hasil kelas tinggi; $n_{1}$ adalah banyaknya sampel pada kelas rendah; $\mathrm{n}_{2}$ adalah banyaknya sampel pada kelas tinggi; $s_{\mathrm{p}}$ adalah deviasi baku gabungan; $s_{p}^{2}$ adalah variansi gabungan; $s_{1}$ adalah deviasi baku dari kelas rendah; $s_{2}$ adalah deviasi baku dari kelas tinggi.

Berikut hasil dari uji beda dua rerata:

1. Hasil Uji-T (Uji Independent Sample T-Test) Menggunakan SPSS Versi 25 diperoleh hasil seperti pada Tabel 5 berikut.

Tabel 5. Hasil Uji-T Menggunakan SPSS Versi 25

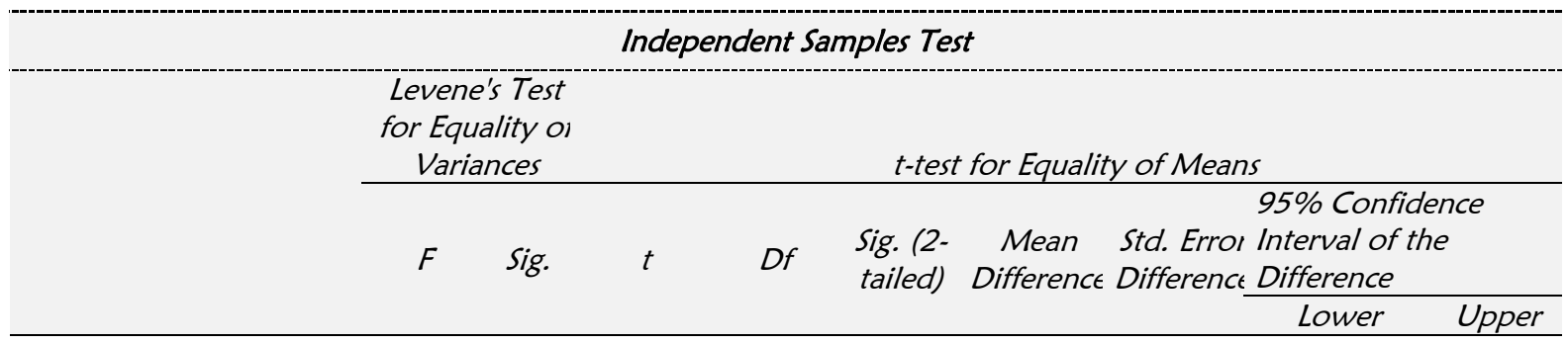




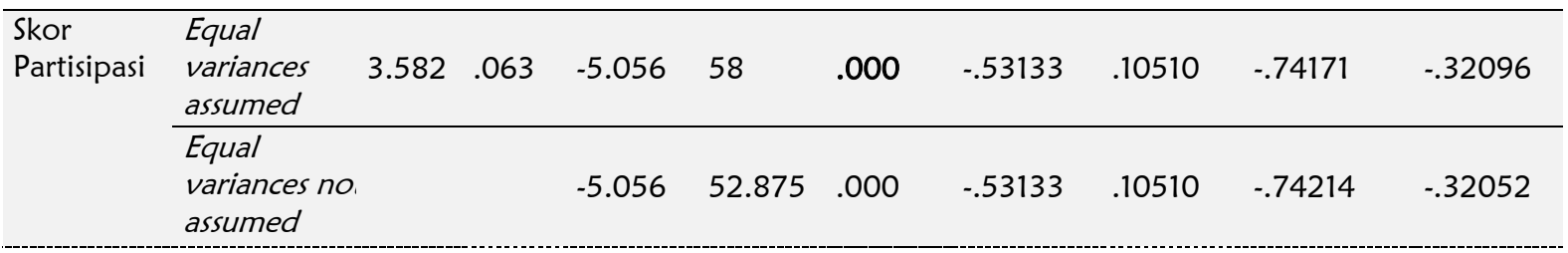

Kriteria pengujian menggunakan taraf signifikan $(\alpha) 5 \%$ :

- Jika nilai Sig. (2-tailed) $>0,05$ maka $\mathrm{H}_{\mathrm{O}}$ diterima dan $\mathrm{H}_{1}$ ditolak

- Jika nilai Sig. (2-tailed) $<0,05$ maka $\mathrm{H}_{0}$ ditolak dan $\mathrm{H}_{1}$ diterima

2. Hasil Uji-T(Uji Independent Sample T-Test) Menggunakan MS. Excel diperoleh hasil seperti pada Tabel 6 berikut.

Tabel 6. Hasil Uji-T Menggunakan MS. Excel

t-Test: Two-Sample Assuming Equal Variances

\begin{tabular}{lcc} 
& Kelas Rendah & Kelas Tinggi \\
\hline Mean & 54.1 & 44.53333333 \\
Variance & 70.3 & 36.94712644 \\
Observations & 30 & 30 \\
Pooled Variance & 53.62356322 & \\
Hypothesized Mean Difference & 0 & DF atau Derajat Kebebasan \\
Df & 58 & Nilai T Hitung \\
$t$ Stat & 5.059742753 & Nilai P value jika di SPSS \\
$P(T<$ adalaht) one-tail & $2.26184 \mathrm{E}-06$ & nilai T tabel \\
$t$ Critical one-tail & 1.671552762 & nilai P value jika di SPSS \\
$P(T<$ adalaht $)$ two-tail & $4.52367 \mathrm{E}-06$ & Nilai T tabel \\
$t$ Critical two-tail & 2.001717484 &
\end{tabular}

Kriteria Pengujian:

- Jika nilai $\mathrm{T}_{\text {hitung }}>\mathrm{T}_{\text {tabel }}(2,0003)$ maka $\mathrm{H}_{0}$ ditolak, $\mathrm{H}_{1}$ diterima

- Jika nilai $\mathrm{T}_{\text {hitung }}<\mathrm{T}_{\text {tabel }}(2,0003)$ maka $_{\mathrm{O}}$ diterima, $\mathrm{H}_{1}$ ditolak

HASIL DAN PEMBAHASAN

Peneliti menghitung data dari hasil penelitian menggunakan statistik deskriptif dengan menggunakan persentase, uji prasyarat analisis, dan uji hipotesis (uji beda dua rerata).

\section{Statistik Deskriptif Dengan Menggunakan Persentase}

1. Partisipasi Orang Tua Di Kelas Rendah

Data partisipasi orang tua terhadap pembelajaran online di rumah pada kelas rendah dengan jumlah sampel 30 orang, kemudian dihitung menggunakan rumus maka diperoleh hasil seperti pada Gambar 1.

Berdasarkan Gambar 1 tampak bahwa partisipasi orang tua di kelas rendah didominasi oleh kategori Baik dengan jumlah 14 orang, berikutnya diikuti oleh kategori Sangat Baik dengan jumlah 12 orang, dan selanjutnya kategori Cukup dengan jumlah 4 orang. Dari hasil tersebut dapat disimpulkan bahwa partisipasi orang tua di kelas rendah termasuk dalam kategori Baik karena jumlah terbanyak pada persentase di $61 \%$ - $80 \%$ dengan rata-rata persentase $75,14 \%$. 


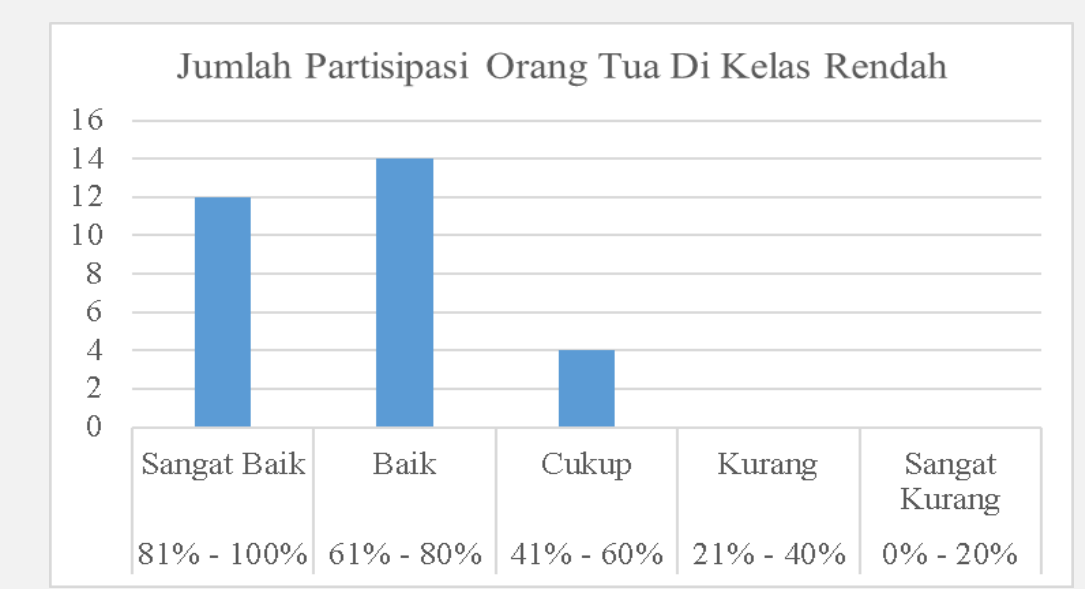

Gambar 1. Diagram Jumlah Partisipasi Orang Tua Di Kelas Rendah

\section{Partisipasi Orang Tua Di Kelas Tinggi}

Data partisipasi orang tua di kelas tinggi dengan jumlah sampel 30 orang, setelah dihitung menggunakan rumus maka diperoleh hasil seperti pada Gambar 2 berikut.

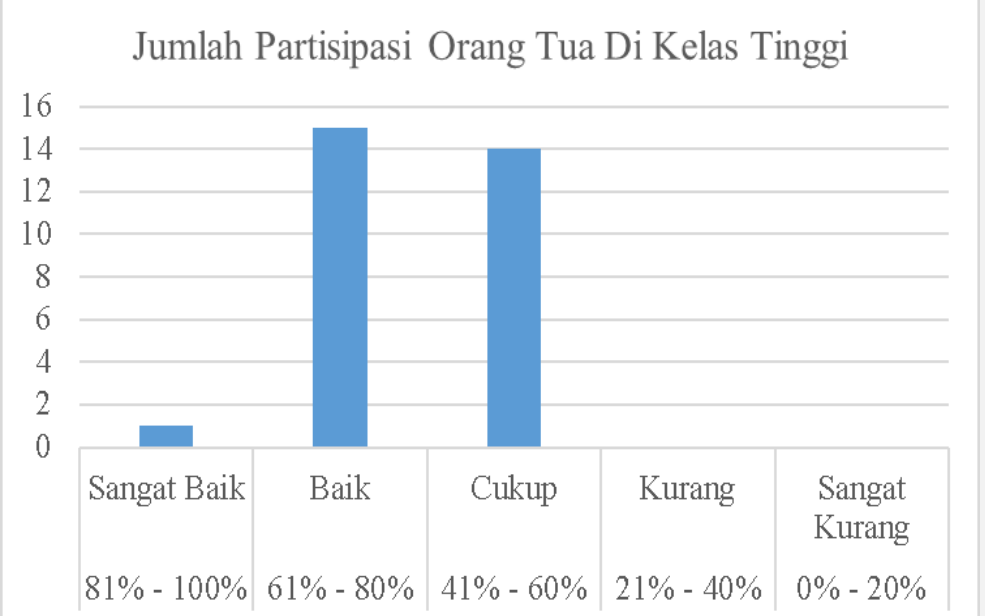

Gambar 2. Diagram Jumlah Partisipasi Orang Tua Di Kelas Tinggi

Berdasarkan diagram tersebut tampak bahwa partisipasi orang tua di kelas rendah didominasi oleh kategori Baik dengan jumlah 14 orang, berikutnya diikuti oleh kategori Sangat Baik dengan jumlah 12 orang, dan selanjutnya kategori Cukup dengan jumlah 4 orang. Dari hasil tersebut dapat disimpulkan bahwa partisipasi orang tua di kelas tinggi termasuk dalam kategori Baik karena jumlah terbanyak pada persentase di $61 \%-80 \%$ dengan rata-rata persentase $61,85 \%$.

\section{Uji Prasyarat Analisis}

\section{Uji Normalitas}

Untuk mengetahui normal atau tidaknya data dilakukan dengan melihat nilai signifikan uji Kolmogorov-Smirnov dengan diperoleh hasil seperti pada Tabel 7 berikut. 
Tabel 7. Hasil Uji Normalitas

\begin{tabular}{lccc}
\hline Data & Sig. Hitung & Standar Sig. & Keterangan \\
\hline $\begin{array}{l}\text { Partisipasi orang tua di kelas } \\
\text { rendah }\end{array}$ & 0,20 & 0,05 & Normal \\
Partisipasi orang tua di kelas tinggi & 0,18 & 0,05 & Normal \\
\hline
\end{tabular}

Berdasarkan Tabel 7 di atas diperoleh nilai Kolmogorov Smirnov untuk data partisipasi orang tua di kelas rendah yaitu 0,20 dan data partisipasi orang tua di kelas tinggi sebesar 0,18. Kedua data tersebut memiliki nilai signifikansinya $>0,05$ maka dapat dikatakan bahwa kedua data tersebut berdistribusi normal dan uji beda dua rerata (uji t) dapat dilakukan.

\section{Uji Homogenitas}

Uji homogenitas digunakan untuk mengetahui apakah sampel yang digunakan dalam penelitian ini homogen atau tidak. Setelah dihitung diperoleh hasil seperti pada Tabel 8. berikut.

Tabel 8. Hasil Uji Homogenitas

\begin{tabular}{ccccccc} 
Data & $\begin{array}{c}\text { Levene } \\
\text { Statistic }\end{array}$ & df 1 & df 2 & $\begin{array}{c}\text { Standar } \\
\text { Sig. }\end{array}$ & $\begin{array}{c}\text { Sig. } \\
\text { Hitung }\end{array}$ & Keterangan \\
\hline $\begin{array}{c}\text { Skor partisipasi } \\
\text { orang tua }\end{array}$ & 3,58 & 1 & 58 & 0,05 & 0,06 & Homogen \\
\hline
\end{tabular}

Berdasarkan tabel di atas bahwa skor partisipasi orang tua memperoleh nilai signifikan sebesar 0,06 yang artinya data di atas memiliki nilai > 0,05 maka dapat dikatakan bahwa data tersebut berdistribusi homogen.

3. Uji Hipotesis (Uji Beda Dua Rerata).

Adapun hipotesis yang digunakan sebagai berikut:

- $\mathrm{H}_{\circ}$ adalahtidak ada perbedaan partisipasi orang tua terhadap pembelajaran online di rumah ditinjau dari fase kelas di Sekolah Dasar.

- $\mathrm{H}_{1}$ adalah ada perbedaan partisipasi orang tua terhadap pembelajaran online di rumah ditinjau dari fase kelas di Sekolah Dasar.

Pada penelitian ini menghitung uji beda dua rerata menggunakan teknik statistik yaitu Independent-Simple $T$ test (Uji t) dengan bantuan SPSS versi 25 , dengan demikian diperoleh hasil seperti pada Tabel 9 berikut.

Tabel 9. Hasil Perhitungan Uji Beda Dua Rerata

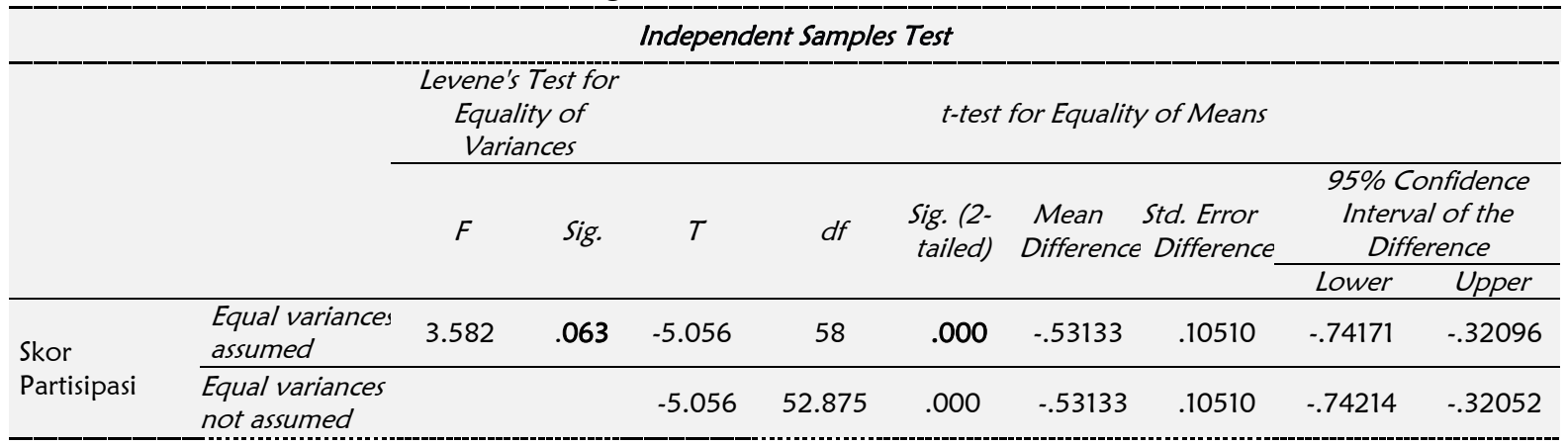

Kriteria Pengujian:

- Jika nilai signifikansi (sig.) $<0,05$ maka $\mathrm{H}_{1}$ ditolak.

- Jika nilai signifikansi (sig.) $>0,05$ maka $\mathrm{H}_{\mathrm{O}}$ diterima. 
Berdasarkan hasil perhitungan uji perbedaan dua rerata data yang disajikan pada Tabel 9 di atas diketahui bahwa pada kolom Levene's Test for Equality of Variances memiliki nilai signifikansi sebesar 0,063 maka nilai tersebut >dari nilai $\alpha$ yaitu 0,05 yang artinya bahwa kedua varians data tersebut adalah sama. Selanjutnya untuk membandingkan rata-rata populasi (t-test for Equality of Means) dalam pengujian t-test harus dengan dasar Equal variances assumed. Pada Equal variances assumed menunjukkan nilai Sig.(2-tailed) $0,000<$ 0,05 yang artinya terdapat perbedaan partisipasi orang tua terhadap pembelajaran online di rumah ditinjau dari fase kelas di Sekolah Dasar.

Hasil hipotesis dalam penelitian ini menyatakan bahwa terdapat perbedaan partisipasi orang tua terhadap pembelajaran online di rumah ditinjau dari fase kelas di Sekolah Dasar. Pada penelitian ini menunjukkan bahwa partisipasi orang tua terhadap pembelajaran online di kelas rendah dan kelas tinggi itu berbeda. Hal ini dikarenakan perhitungan menggunakan SPSS versi 25 pada kolom Equal variances assumed yang menunjukkan bahwa nilai Sig.(2-tailed) $0,000<0,05$ dan perhitungan menggunakan MS. Excel pada kolom $t$-Stat menunjukkan

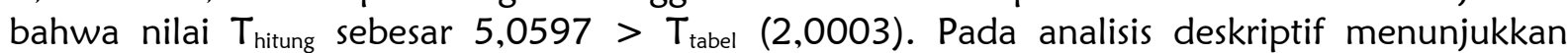
bahwa nilai rata-rata partisipasi orang tua terhadap pembelajaran online di kelas rendah berjumlah $75,14 \%$ masuk dalam kategori baik dan untuk nilai rata-rata partisipasi orang tuaterhadap pembelajaran online di kelas tinggi berjumlah $61,85 \%$ masuk dalam kategori baik.

Nilai rata-rata persentase partisipasi orang tua terhadap pembelajaran online di kelas rendah $\geq$ nilai rata-rata persentase di kelas tinggi, maka dengan demikian partisipasi orang tua terhadap pembelajaran online di kelas rendah lebih tinggi dibanding di kelas tinggi. Hal ini dikarenakan karakteristik anak di kelas rendah itu masih senang bermain dan susah diminta untuk belajar, maka partisipasi orang tua dalam masa ini sangat dibutuhkan. Endramoyo (2018) mengungkapkan bahwa siswa kelas rendah masih banyak membutuhkan perhatian karena konsentrasinya masih kurang, perhatian terhadap kecepatan dan aktivitas belajar yang lebih menarik dan lebih efektif. Sedangkan partisipasi orang tua di kelas tinggi lebih rendah tingkat partisipasinya dikarenakan karakter anak kelas IV, V, VI lebih mandiri serta daya berpikirnya lebih cepat sehingga peran serta orang tua dalam mendampingi belajar tidak begitu banyak. Menurut Restian (2019) karakteristik anak pada kelas tinggi antara lain: waktu untuk merespon perintah lebih cepat, koordinasi dan harmonisasi otot sempurna, senang bergerak dan bermain.

Berdasarkan karakteristik siswa di kelas rendah dan kelas tinggi, partisipasi orang tua yang masih sangat dibutuhkan untuk mendampingi siswa belajar yaitu di kelas rendah karena pada pada usia 7-9 tahun siswa belum mampu untuk belajar secara mandiri dan mereka lebih senang untuk bermain, sehingga pertisipasi dari orang tua sangat diperlukan. Apalagi pembelajaran yang saat ini yang diterapkan yaitu pembelajaran online, sehingga dengan adanya partisipasi dari orang tua proses belajar siswa lebih terarah dan terbimbing dengan demikian prestasinya pun akan lebih baik. Pembelajaran online yaitu pembelajaran jarak jauh dimana guru dan siswa tidak tatap muka secara langsung melainkan lewat internet dengan bantuan menggunakan HP android atau Smartphone. Menurut Yuliani, et al. (2020) pembelajaran online yaitu kegiatan belajar mengajar yang tidak terikat ruang, waktu, serta kehadiran guru, dengan menggunakan sarana elektronik dan telekomunikasi.

Pentingnya partisipasi orang tua dalam pembelajaran online yaitu dengan adanya peran serta dari orang tua maka kegiatan pembelajaran online di rumah dapat berjalan lancar dan baik. Bentuk partisipasi yang dapat orang tua diberikan ke siswa saat mengikuti pembelajaran online dapat berupa orang tua sebagai pendidik, pembimbing, motivator, serta fasilitator. Bentuk partisipasi orang tua tersebut juga didukung oleh penelitian Lilawati (2020) yang mengungkapkan bahwa pengaruh yang paling dirasakan saat siswa mengikuti pembelajaran online di rumah yaitu orang sebagai motivator, karena minat dan motivasi siswa meningkat bila diberikan kepercayaan dan tanggung jawab untuk mengasah bakat dan potensi yang dimiliki siswa. 
Pencapaian masing-masing indikator partisipasi orang tua di kelas rendah dan kelas tinggi disajikan pada Tabel 10.

\begin{tabular}{ccc} 
Tabel 10. Pencapaian Indikator Partisipasi Orang Tua \\
\hline Indikator & Kelas Rendah & Kelas Tinggi \\
\hline 1 & $75,55 \%$ & $60,55 \%$ \\
2 & $74,66 \%$ & $60,16 \%$ \\
3 & $72,22 \%$ & $62,22 \%$ \\
4 & $76,64 \%$ & $63,45 \%$ \\
\hline
\end{tabular}

Pencapaian indikator tertinggi partisipasi orang tua di kelas rendah dan kelas tinggi yaitu pada indikator orang tua sebagai fasilitator. Pada kelas rendah pencapaian sebesar 76,64\% dan pada kelas tinggi sebesar $63,45 \%$. Hal ini disebabkan karena sebagian besar orang tua siswa di kelas I, II, dan III masih memperhatikan keperluan apa yang saja yang dibutuhkan siswa untuk dapat mengikuti kegiatan pembelajaran online, karena siswa tersebut belum mampu menyiapkan sendiri apa saja keperluan yang mereka butuhkan. Menurut Hamid (2020) orang tua sebagai fasilitator siswa, maksudnya yaitu proses pembelajaran pada siswa akan berhasil dan lancar jika fasilitas penunjang untuk belajar siswa tersedia dengan cukup.

Pencapaian indikator terendah pada partisipasi orang tua di kelas rendah yaitu orang tua sebagai motivator sebesar $72,22 \%$. Hal ini disebabkan karena kurangnya bentuk motivasi yang orang tua berikan kepada siswa seperti, mereka hanya sesekali saja memberikan pujian dan menyemangati siswa saat belajar dibuktikan dari hasil angket yang orang tua berikan. Menurut Hamid (2020) orang tua sebagai motivator siswa, artinya siswa dapat termotivasi untuk bertindak jika mendapat dorongan dari orang lain terutama yaitu orang tua. Bentuk motivasi yang dapat diberikan yaitu berupa: dorongan, pemberian penghargaan dan hadiah.

Pencapaian indikator terendah pada partisipasi orang tua di kelas tinggi yaitu pada indikator orang tua sebagai pembimbing sebesar $60,16 \%$. Hal ini disebabkan karena siswa kelas IV, V, dan VI mereka merasa sudah bisa untuk mandiri sehingga peran serta orang tua dalam mendampingi belajar tidak begitu banyak. Menurut Hamid (2020) orang tua sebagai pembimbing siswa, artinya dalam keluarga terutama orang tua dapat memberikan bimbingan serta memberikan contoh teladan yang baik kepada siswa dalam segala aktivitasnya.

Berdasarkan hasil pembahasan di atas dapat tarik kesimpulan bahwa partisipasi orang tua terhadap pembelajaran online di rumah berupa: orang tua sebagai pendidik, pembimbing, motivator dan fasilitator. Partisipasi orang tua terhadap pembelajaran online di kelas rendah $\geq$ kelas tinggi dikarenakan karakter dari siswa kelas rendah itu sendiri mereka masih senang bermain dan susah diminta untuk belajar, sehingga partisipasi orang tua dalam masa ini sangat dibutuhkan. Sedangkan untuk siswa kelas tinggi mereka lebih mandiri serta daya berpikirnya lebih cepat sehingga peran serta orang tua dalam mendampingi belajar tidak begitu banyak.

Berdasarkan penelitian yang telah dilakukan terdapat kendala yang dialami peneliti saat pengambilan data, yaitu saat penyebaran angket penelitian yang rencana awalnya dilakukan di dalam kelas dengan membagikan angket kepada siswa kelas I-VI yang kemudian mereka berikan kepada masing-masing orang tua siswa, namun karena saat pengambilan data di SD Negeri 1 Seren saat itu ditutup sementara waktu karena peningkatan kasus Covid-19 di Purworejo sehingga saya sebagai peneliti harus membagikan angket penelitian ke masingmasing rumah siswa sebanyak 60 angket.

\section{KESIMPULAN}

Partisipasi orang tua yaitu keterlibatan diri orang tua kepada anak ataupun orang lain dalam mendukung ketercapainya suatu tujuan dan ikut serta bertanggung jawab. Keberhasilan siswa dalam belajar ditentukan dari bagaimana partisipasi yang orang tua berikan terhadap siswa. Partisipasi orang tua dalam mendukung kegiatan pembelajaran online pada siswa diberikan dalam bentuk orang tua sebagai pendidik, pembimbing, motivator dan fasilitator. 
Selanjutnya hasil uji hipotesis pada penelitian ini diperoleh nilai Sig.(2-tailed) $0,000<0,05$ menunjukkan terdapat perbedaan partisipasi orang tua terhadap pembelajaran online di rumah ditinjau dari fase kelas di Sekolah Dasar. Rata-rata persentase partisipasi orang tua terhadap pembelajaran online di kelas rendah yaitu 75,14\% lebih besar dibandingkan rata-rata partisipasi orang tua terhadap pembelajaran online di kelas tinggi yaitu $61,85 \%$ sehingga partisipasi orang tua terhadap pembelajaran online di kelas rendah lebih baik.

\section{UCAPAN TERIMA KASIH}

Ada banyak pihak yang telah membantu dalam penelitian ini, oleh karena itu peneliti menyampaikan terima kasih kepada: Dr. Rofiq Nurhadi, M. Ag., Rektor Universitas Muhammadiyah Purworejo yang telah memberikan kesempatan kepada penulis untuk menuntut ilmu di perguruan ini; Yuli Widiyono, M.Pd, Dekan Fakultas Keguruan dan Ilmu Pendidikan yang telah memberikan ijin untuk mengadakan penelitian; Siti Jaenah, S.Pd.,SD, MM.Pd., Kepala SD Negeri 1 Seren yang telah memberikan ijin untuk mengadakan peneliti; Para orang siswa SD Negeri 1 Seren yang bersedia membantu dalam pelaksanaan penelitian dan mengambil data.

\section{DAFTAR PUSTAKA}

Belawati, T. (2019). Pembelajaran Online. Banten: Universitas Terbuka

BNBP. (2020). Nomor 9.A Tahun 2020 tentang Penetapan Status Keadaan Tertentu Darurat Bencana Wabah Penyakit Akibat Virus Corona di Indonesia. Jakarta.

Bungin, B. (2013). Metode Penelitian Kuantitatif (komunikasi, ekonomi, dan kebijakan publik serta ilmu-ilmu sosial lainnya). Jakarta: Kencana.

Cahyati, N., \& Kusumah, R. (2020). Peran orang tua dalam menerapkan pembelajaran di rumah saat pandemi Covid 19. Jurnal Golden Age, 4(01), 152-159.

Dwiningrum, S. I. A. (2011). Desentralisasi dan partisipasi masyarakat dalam pendidikan. Pustaka Pelajar.

Endramoyo, W. (2018). Cakram Matemawiku Inovasi Cerdas Matematika Dasar. Jakarta: Indocamp.

Hamid, A. (2020). Memaknai Kehidupan. Banten: Makmood Publishing.

Lilawati, A. (2020). Peran Orang Tua dalam Mendukung Kegiatan Pembelajaran di Rumah pada Masa Pandemi. Jurnal Obsesi: Jurnal Pendidikan Anak Usia Dini, 5(1), 549-558. https://doi.org/10.31004/obsesi.v5i1.630

Restian, A. (2019). Koreografi Seni Tari Berkarakter Islami untuk Anak Sekolah Dasar (Vol. 1). UMMPress.

Somawati, A. V., Adnyana, K. S., Darmawan, I. P. A., Dewi, N. P. D. U., Untara, I. M. G. S., Suadnyana, I. B. P. E., ... \& Indrayasa, K. B. (2020). Bali vs COVID-19: Book Chapters. Nilacakra.

Sugiyono. (2016). Statistik Untuk Penelitian. Bandung: Alfabeta.

Widoyoko, S. E. P. (2018). Teknik Penyusunan Instrumen Penelitian. Yogyakarta: Pustaka Pelajar. 
Yuliani, M., Simarmata, J., Susanti, S. S., Mahawati, E., Sudra, R. I., Dwiyanto, H., ... \& Yuniwati, I. (2020). Pembelajaran Daring untuk Pendidikan: Teori dan Penerapan. Yayasan Kita Menulis.

Zarkasyi, W. (2017). Penelitian Pendidikan Matematika. Bandung: Refika Aditama. 